\title{
Water-Table Elevations on the Hanford Site, December 1989
}

D. R. Newcomer

J. P. McDonald

June 1990

Prepared for the U.S. Department of Energy under Contract DE-AC06-76RLO 1830

Pacific Northwest Laboratory

Operated for the U.S. Department of Energy by Battelle Memorial Institute 


\title{
DISCLAIMER
}

This report was prepared as an account of work sponsored by an agency of the United States Government. Neither the United States Government nor any agency thereof, nor Battelle Memorial Institute, nor any of their employees, makes any warranty, expressed or implied, or assumes any legal liability or responsibility for the accuracy, completeness, or usefulness of any information, apparatus, product, or process disclosed, or represents that its we would not infringe privately owned rights. Reference herein to any specific commercial product, process, or senice by trade name, trademark, manufacturer, or otherwise, does not necessarily constitute or imply its endorsement, recoinmendation, or favoring by the United States Government or any agency thereof, or Battelle Memorial Institute. The views and opinions of authors expressed herein do not necessarily state or reflect those of the United States Government or any agency thereof.

\author{
PACIFIC NORTHWEST LABORATORY \\ operated by \\ BATTELLE MEMORIAL INSTITUTE \\ for the \\ UNITED STATES DEPARTMENT OF ENERGY \\ under Contract DE-ACO6-76RLO 1830
}

Printed in the United States of America

Available to DOE and DOE contractors from the

Office of Scientific and Technical Information, P.O. Box 62, Oak Ridge, TN 37831; prices available from (615) 576-8401. FTS 626-840!.

Available to the public from the National Technicat Information Service.

U.S. Deparment of Commerce, 5285 Port Royal Rd., Springfield, VA 22161.

NTIS Price Codes, Microfiche A01

Printed Copy

\begin{tabular}{|c|c|c|c|}
\hline Price Code & Page Range & Price Code & Page Range \\
\hline $\mathrm{A} 02$ & $1-10$ & A 15 & $326-350$ \\
\hline $\mathrm{A} 03$ & $11-50$ & A16 & $351-375$ \\
\hline $\mathrm{A} 04$ & 51.75 & A 17 & $376-400$ \\
\hline A05 & $76-100$ & $A: B$ & $401-425$ \\
\hline$A 06$ & $101-125$ & A 19 & $426-450$ \\
\hline $\mathrm{A} 07$ & $126-150$ & $\mathrm{~A} 20$ & $451-475$ \\
\hline$A 0 B$ & $15:-175$ & $\mathrm{~A} 2 \pm$ & 476.500 \\
\hline A09 & $176-200$ & $\mathrm{~A} 22$ & $501+525$ \\
\hline A 10 & $201-225$ & A23 & 526.550 \\
\hline A11 & $226-250$ & $\mathrm{~A} 24$ & $551-575$ \\
\hline A $: 2$ & $251-275$ & A25 & $576-600$ \\
\hline A13 & 276.300 & A99 & $601-\mathrm{U}_{\mathrm{p}}$ \\
\hline A 14 & $301-325$ & & \\
\hline
\end{tabular}


WATER-TABLE ELEVATIONS ON THE

HANFORD SITE, DECEMBER 1989

\author{
D. R. Newcomer \\ J. P. McDonald
}

June 1990

Prepared for

the U.S. Department of Energy

under Contract DE-AC06-76RLO 1830

Pacific Northwest Laboratory

Richland, Washington 99352 
. 


\section{SUMMARY}

The Pacific Northwest Laboratory prepared water-table maps of the U.S. Department of Energy's Hanford Site for December 1989 from water-Tevel elevations measured in 225 wells across the Hanford Site. Changes in the elevation of the water table at Hanford occurred beneath the decomissioned $U$ Pond in 200-West Area, B Pond, and 100-N Area. The elevation of the groundwater mound beneath the decommissioned $U$ Pond generally continued to decline, decreasing as much as $0.28 \mathrm{~m}(0.9 \mathrm{ft})$ between June and December 1989. This decline has been observed in wells in much of the adjacent 200-West Area and is primarily the result of continued dissipation of the ground-water mound beneath $U$ Pond since it was deactivated in 1984. The elevation of the groundwater mound beneath $B$ Pond, which continues to receive wastewater, also declined as much as $0.28 \mathrm{~m}(0.9 \mathrm{ft})$ between June and December 1989. This decline in the water table is primarily the result of decreasing volumes of wastewater discharged to B Pond.

The greatest change in the elevation of the water table occurred beneath the 1325-N liquid waste disposal facility in the 100-N Area. The elevation of the water table beneath this facility decreased as much as $5.96 \mathrm{~m}(19.6 \mathrm{ft})$ between June and December 1989.

Other Hanford discharge facilities known to impact the ground-water flow system include the process trenches in the 300 Area and various cribs and trenches in the 200 Areas. 



\section{CONTENTS}

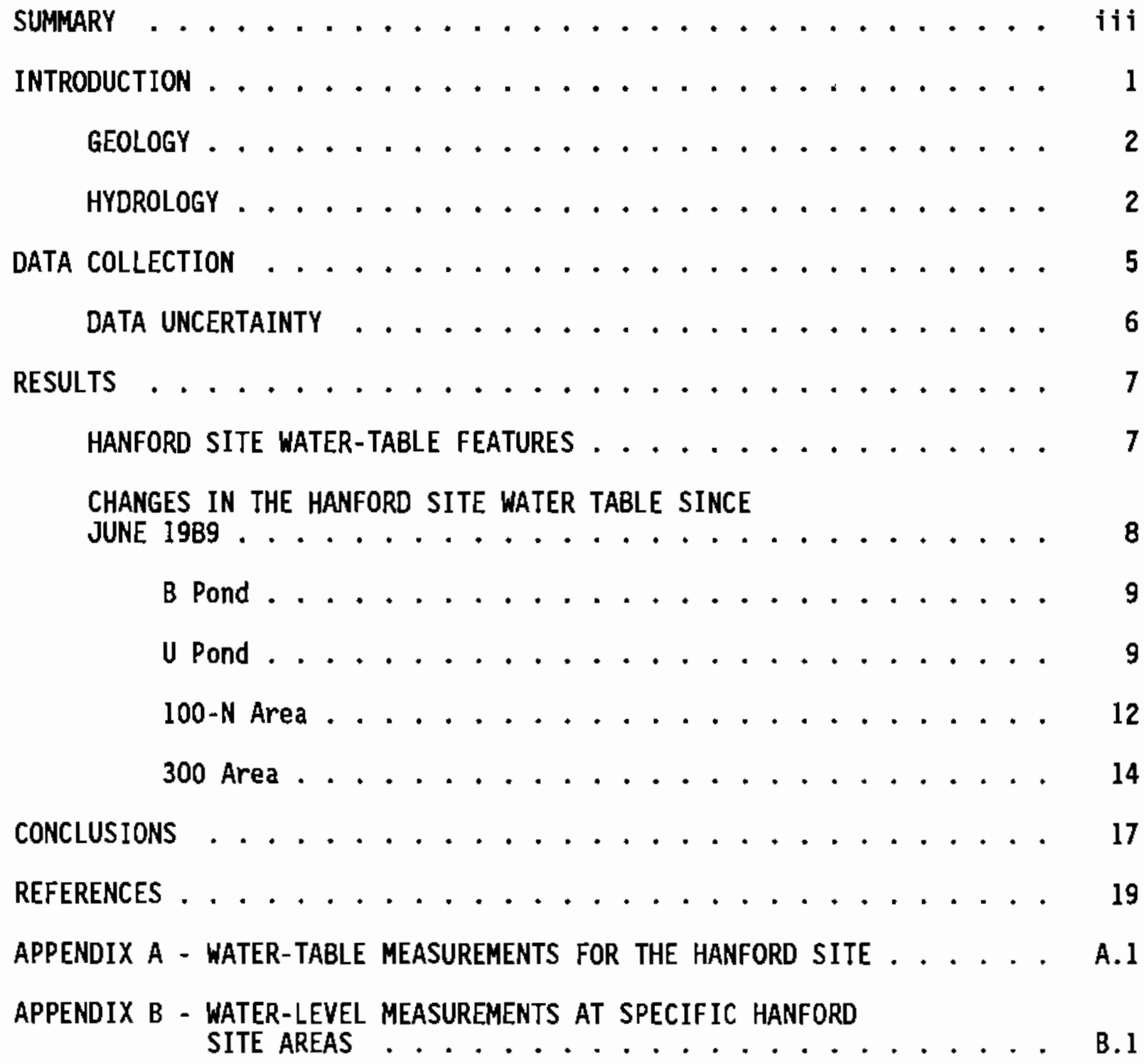




\section{FIGURES}

1 Water-Tabie Map of the Area Beneath B Pond for December 1989 . . 10

2 Water-Table Map of the Area Beneath the Decommissioned

U Pond in the 200-West Area for December 1989 ......... 11

3 Water-Table Map of the Area Beneath the 1325-N Liquid Waste

Disposal Facility in the 100-N Area for December $1989 \ldots 13$

4 Water-Table Map of the Area Beneath the 300 Area for

December 1989 ................... 15

Plate 1................................. Inside Back Cover 


\section{INTRODUCTION}

The Site Characterization and Assessment Section, Environmental Sciences Department, of the Pacific Northwest Laboratory (PNL) prepares water-table maps of the Hanford Site in southeastern Washington. Production of these maps supports the Ground-Water Environmental Surveillance Program, which is sponsored by the U.S. Department of Energy (DOE).

Water levels in selected wells open to the unconfined aquifer on the Hanford Site are measured in June and December of each year. The purpose of these measurements is to determine the changes in the configuration of the water table to assess the physical impact of waste disposal on ground-water flow.

Water-leve1 measurements can be used to construct a water-table map that represents the elevation of the water-table surface. These maps can be used to infer general directions of ground-water flow, particularly in the upper part of the aquifer. Ground water moves from regions of higher water-table elevations to regions of lower water-table elevations perpendicular to contours of equal water-table elevation, assuming conditions of isotropic hydrautic conductivities. Water-table maps can be used to

- identify recharge and discharge areas

- evaluate the physical influence of wastewater discharges on groundwater flow directions

- determine the potential for water movement between adjacent groundwater and surface water bodies

- determine the horizontal hydraulic gradient and estimate the average linear velocity of ground-water flow

- improve the design of the water-level monitoring well network.

Also, water-level data used to construct water-table maps are required to calibrate ground-water models.

In addition to water levels measured across the Hanford Site, water Tevels were also measured from four specific areas within Hanford. Included are areas around the decommissioned 216-U-10 Pond (U Pond), the 216-B-3 Pond 
(B-Pond), the 100-N Area, and the 300 Area. The locations of these areas are shown in Plate 1 (located in the pocket inside the back cover). Water-table maps of these areas are intended to enhance the definition of the water-table configuration beneath wastewater discharge facilities that may impact groundwater flow.

Water-leve 1 measurements and a water-table elevation map of the Hanford Site for June 1989 are presented in Newcomer et a]. (1990). Water-level measurements and a water-table map of the Separations Areas for June 1989 are presented in Kasza et al. (1989). The Separations Areas encompass the 200-East and 200-West Areas and the surrounding vicinity on the Hanford Site. Historical water-level data and an evaluation of past changes to the water-table surface are presented in Zimnerman et a1. (1986).

Water-levels are measured in wells that monitor the unconfined aquifer. The wells used to measure water-levels were chosen based on geologic and hydrologic information available. A sumnary of the geology and hydrology of the Hanford Site follows.

\section{GEOLOGY}

The Hanford Site lies within the Pasco Basin, one of many topographic and structural basins within the Columbia Plateau. Principal geologic units beneath the Hanford Site include, in ascending order, the Columbia River Basalt Group, the Ringold Formation, and a series of deposits informalty referred to as the Hanford formation. These units are covered locally by a few meters or less of recent alluvial or windblown deposits. 0lder geologic units have been deformed into a series of roughly east-west trending folds.

\section{HYDROLOGY}

Both confined and unconfined aquifers are present beneath the Hanford Site. The confined aquifers lie primarity within the Columbia River basalts. The unconfined aquifer lies in river and lake deposits of the Ringold Formation and glaciofluvial sediments of the Hanford formation, as well as some more recent alluvial sediments in areas adjacent to the Columbia River (Gephart et a1. 1979). 
The unconfined aquifer is bounded below by either the basalt surface or, in places, the relatively impervious clays and silts of the lower unit of the Ringold Formation. Laterally, the unconfined aquifer is bounded by the basalt ridges that surround the basin and by the Yakima and Columbia rivers. The basalt ridges have a low permeability and act as a barrier to lateral flow of ground water (Gephart et al. 1979) where they rise above the water table. The saturated thickness of the unconfined aquifer is greater than $61 \mathrm{~m}(200 \mathrm{ft})$ in some areas of the Hanford Site and pinches out along the flanks of the basalt ridges. Depth from the ground surface to the water table ranges from less than $0.3 \mathrm{~m}(1 \mathrm{ft})$ near the Columbia River to more than $106 \mathrm{~m}(348 \mathrm{ft})$ near the 200 Areas. 


\section{DATA COLLECTION}

During December 1989 water levels were measured across the Hanford Site in 225 wells open to the unconfined aquifer. Additional measurements were taken in 98 wells near $U$ Pond, B Pond, the 100-N Area, and the 300 Area. Most monitoring wells at the Hanford Site used for water-level measurement are 15 or $20 \mathrm{~cm}$ ( 6 or $8 \mathrm{in.}$ ) in diameter and are constructed of steel casing. Several smal]-diameter [5-cm (2-in.)] piezometers and some larger diameter wells are also used. New wells constructed for Resource Conservation and Recovery Act ground-water monitoring are $10 \mathrm{~cm}$ (4 in.) in diameter. Monitoring wells used to measure water levels for the unconfined aquifer are completed with well screens or perforated casing generally open to the upper 3 to $6 \mathrm{~m}$ (10 to $20 \mathrm{ft}$ ) of the aquifer. This type of completion allows measurements representative of the water-table elevation. Well locations for water-level monitoring are shown in Plate 1.

Wells were added to the water-leve1 monitoring network for December 1989 in areas where little information exists for estimating the water-table contours. The most notable area where wells were added include the area north of B Pond bordering the southern edge of Gable Mountain (see P1ate 1). A few wells were removed from the network to eliminate redundancy in taking measurements in closely spaced wells where the gradient of the water table is very small (e.g., northern perimeter of the 200-East Area).

Five new wells, installed in 1989 , were added to the water-level monitoring network at $B$ Pond. These wells are located along the perimeter of the ponds and near the 216-A-29 Ditch.

A written procedure developed in accordance with the techniques described in ASTM (1988), EPA (1986), Garber and Koopman (1968), and USGS (1977) was followed to measure water levels in piezometers and wells (PNL 1989). A chalked standardized steel tape was used to measure the depth to the water surface in units of feet from a surveyed measuring point. These measurements were repeated to confirm the initial value. If the second measurement differed by more than $0.02 \mathrm{ft}$ from the first, the water level was remeasured until two 
measurements within this tolerance were obtained. Measurements were compared to previous measurements of depth to water to provide a check for gross errors.

Elevation of the water-table was determined from the depth-to-water measurements. The values were calculated by subtracting the depth-to-water measurements from the surveyed measuring point elevations on the well casings. The reference for all measuring point elevations is mean sea level. The elevation of the water-table surface, $S$, can be expressed as:

$$
S=E-D
$$

where $S=$ elevation of the water-table surface above mean sea level

$E=$ elevation of surveyed measuring point above mean sea level

$D=$ depth to the water-level surface in the piezometer or well, measured below the surveyed measuring point.

All depth-to-water measurements are conducted within a 3-week period to minimize the effects of long-term, time-variant water-level changes.

Steel tapes were standardized against a calibrated steel tape at a selected well at Hanford. This standardization procedure is documented in PNL (1989).

\section{DATA UNCERTAINTY}

A11 water-level measurements are collected within a 3 -week period. The greatest short-term water-level changes that occur within this period are in wells influenced by the rise and fall of the Columbia River stage. This may cause some variability in the location of the water-table contours adjacent to the river. Other minor uncertainties in the water-level measurements are caused by effects from diurnal changes (e.g., barometric effects), deviations from the vertical installation of wells, errors in the elevation of the surveyed measuring points, and errors in the standard tolerances of the field equipment. 


\section{RESULTS}

Water levels measured during December 1989 for the Hanford Site watertable map are listed in Appendix A. Water levels measured during December 1989 for specific areas within the Hanford Site are 1isted in Appendix B. The Hanford Site water-table map, presented in $\mathrm{Pl}$ ate 1 , was constructed by hand-contouring the values for the water-table elevation. The contours in Plate 1 are in units of meters. To allow the map to be more easily read, the prefixes have been omitted from all well numbers shown on the map. Well numbers in the 100 Areas have the prefix 199, well numbers in the 200-East and 200-West Areas have the prefix 299, well numbers in the 300 Area have the prefix 399 , and well numbers in the 600 Area have the prefix 699.

\section{HANFORD SITE WATER-TABLE FEATURES}

The following are important features of the Hanford Site water-table map:

- Water-table elevations generally decrease from west to east across the Hanford Site south of Gable Mountain and Gable Butte.

- Water-table elevations decrease northward through the gap between Umtanum Ridge and Gable Butte and between Gable Butte and Gable Mountain.

- The hydraulic gradient of the water table decreases abruptly between the 200-West and 200-East Areas.

- The water level in the Yakima River is of higher elevation than that of the water table in the adjacent region of the Hanford Site.

- Ground-water mounds are present beneath B Pond and the location of decomisissioned U Pond.

Elevated water levels in the western region of the Hanford Site may be attributable to ground-water recharge in Cold Creek and Dry Creek valleys and on the adjacent ridges (i.e., Yakima, Umtanum, and Rattlesnake Ridges). The source of recharge is most likely infiltration of rain and snow at the higher elevations and excess irrigation of agricultural land at the lower elevations.

Water-table elevation generally decreases toward the Columbia River at the eastern edge of the Hanford Site and north of the Gable Mountain-Gable 
Butte anticline, implying discharge of unconfined ground water to the Columbia River along the Hanford reach (the free-flowing stretch of the Columbia River between Priest Rapids Dam and the city of Richland).

The abrupt change in the hydraulic gradient of the water table between the 200-West and 200-East Areas is attributed to an increase in the hydraulic conductivity of the sediments from west to east (Graham et al. 1981).

A water-table elevation lower than the Yakima River in the region between Horn Rapids Dam and the city of Richland implies that the unconfined aquifer is being recharged by the Yakima River. Water levels measured in this region also indicate that ground water recharged by the Yakima River flows to the east beneath the southern portion of the Hanford Site and discharges to the Columbia River.

Ground-water mounds beneath B Pond and the location of the decommissioned $U$ Pond have been caused by process cooling water and other liquid wastes recharging the ground water at those locations. A summary of wastewater discharges to disposal facilities in the 200 Areas is presented by Cooney and Thomas (1989).

\section{CHANGES IN THE HANFORD SITE WATER TABLE SINCE JUNE 19B9}

The greatest change to the ground water at Hanford occurred beneath $B$ Pond, located east of the 200-East Area, beneath the decommissioned $U$ Pond in the 200-West Area, and beneath the 1325-N liquid waste disposal facility in the 100-N Area. Wastewater recharging the ground water at those locations has caused large ground-water mounds. Wastewater discharges to the process trenches in the 300 Area have also impacted the ground water. A summary of waste discharges to disposal facilities in the 200 and 600 Areas for 1988 is presented by Cooney and Thomas (1989).

The elevation of the water table beneath the 200 Areas declined between June 1989 and December 1989. This decline is primarily attributed to I) an overa11 decrease in wastewater discharged to the ground surface at B Pond and various cribs and trenches in the 200 Areas and 2) continued dissipation of the ground-water mound beneath U Pond since it was decommissioned in 1984 . 
Water-level changes also occurred in wells near the Columbia River. These water-level changes indicate that the water table fell as much as $0.3 \mathrm{~m}$ (1 ft) along the Columbia River between June and December 1989. These changes are primarily the result of changes in bank storage caused by the fall of the river stage. The Columbia River stage changes in response to releases at the Priest Rapids Dam upstream from the Hanford reach and to seasonal influences.

\section{B Pond}

A map of the water table beneath B Pond is presented in Figure 1. This map indicates that ground water flows radially from beneath $B$ Pond. The elevation of the water table beneath $B$ Pond has decreased as much as $0.28 \mathrm{~m}$ $(0.9 \mathrm{ft}$ ) since June 1989 (as reflected in the water level in well 699-42-40B). This decline in the elevation of the water table reflects the general decrease in wastewater discharged to B Pond.

An exception to this water-level change is the water level in well 699-39-39, located south of B Pond. The water level in this well decreased $0.67 \mathrm{~m}(2.2 \mathrm{ft})$ between June 8,1989 , and December 7,1989 , using the Hanford Site measurements. However, between December 7, and December 21, 1989, the water level increased $0.43 \mathrm{~m}(1.4 \mathrm{ft})$, to an elevation higher than the nearest well 699-40-39. Because the water level in well 699-39-39 is higher than expected relative to water levels in other wells at B Pond, the configuration of the water table in the vicinity of this well cannot be determined (see Figure 1). The water level in this well has been changing significantly since 1987, rising as much as $2.2 \mathrm{~m}(7.2 \mathrm{ft})$ in 1988 and falling as much as $2.1 \mathrm{~m}$ $(6.9 \mathrm{ft})$ in 1989. Water-table maps of the B Pond area for June 1989 are presented in Kasza et a1. (1989) and Newcomer et al. (1990). A water-table map of B Pond for November 1989 is presented in Smith and Gorst (1990).

\section{$\underline{\cup \text { Pond }}$}

A map of the water table beneath the decommissioned $U$ Pond is presented in Figure 2. This map indicates that ground water flows radially, mostly to the north and east from an area near the 216-U-14 Ditch, located east-northeast of the decommissioned $U$ Pond. This ditch continues to receive cooling water 


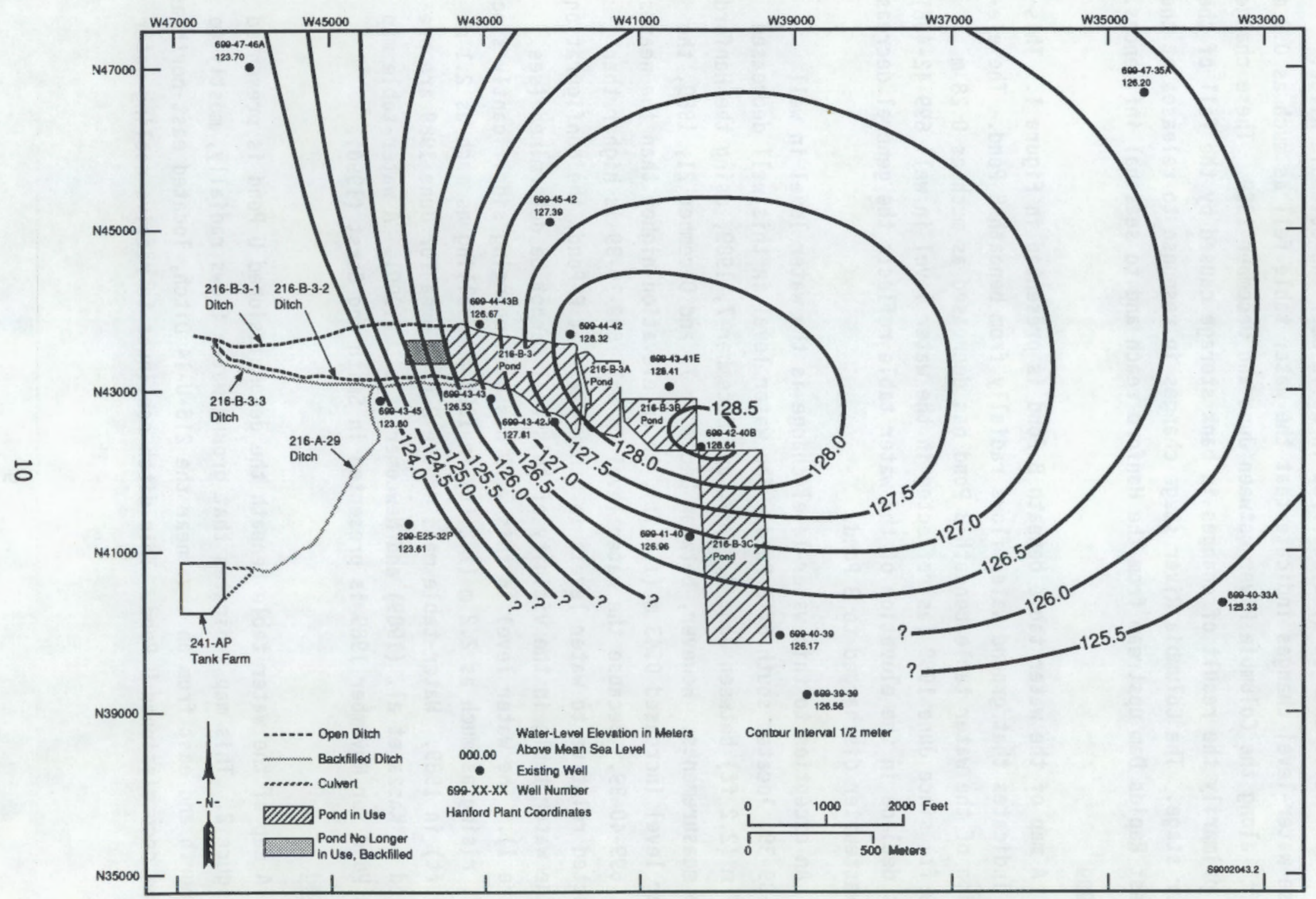

FIGURE 1. Water-Table Map Beneath B Pond for December 1989 


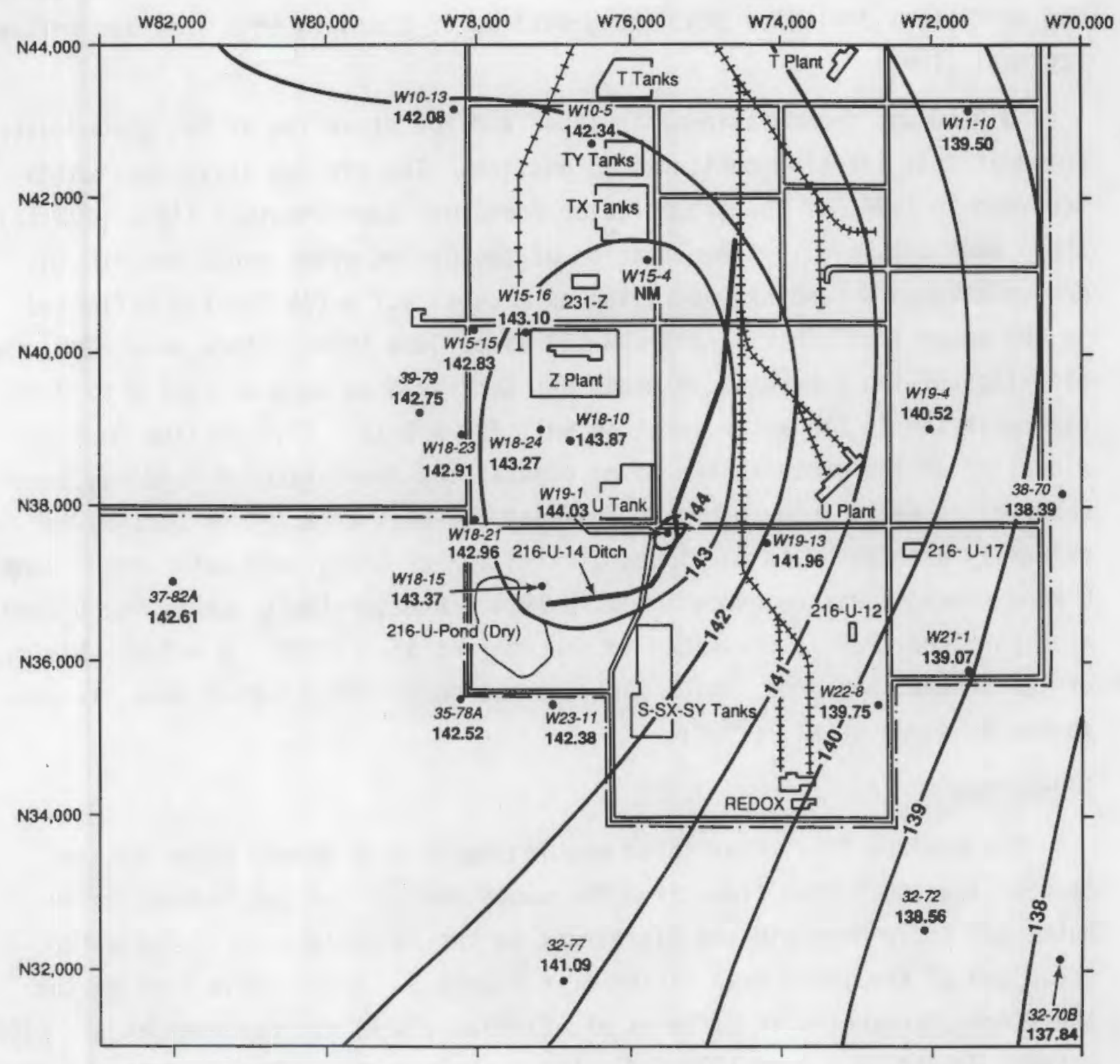

NM No Measurement

- W22-8 Well Location and Number (Well Prefixed by 199 - or 699 - as Appropriate)
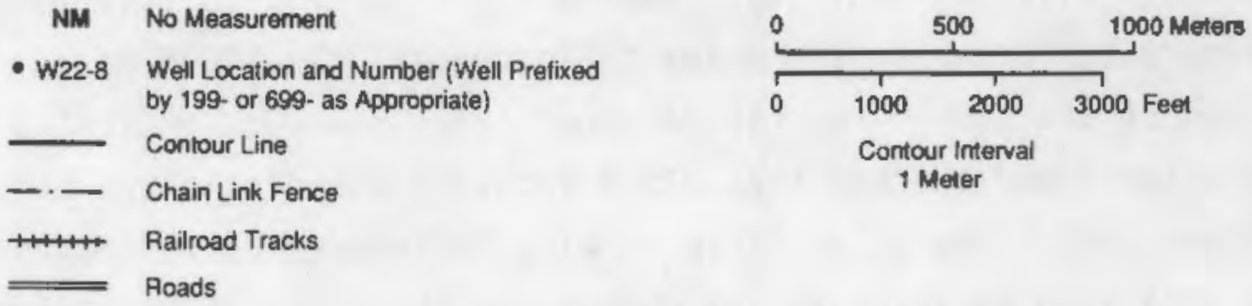

Hanford Plant Coordinates

FIGURE 2. Water-Table Map of the Area Beneath the Decommissioned $U$ Pond in the 200-West Area for December 1989 
and steam condensate (Cooney and Thomas 1989). The Hanford Site water-table map in Plate 1 indicates that the ground-water mound in this area has influenced regional flow.

U Pond was decommissioned in 1984, and the elevation of the ground-water mound at that location continues to decline. The maximum elevation, which occurred in 1984, of the ground-water mound was approximately $148 \mathrm{~m}$ (485 ft) above mean sea level. The elevation of the ground-water mound beneath the decommissioned $U$ Pond has decreased as much as $4.7 \mathrm{~m}$ (15 ft) (as reflected in the water level in well 299-W18-15) since June 1984. Since June 1989, the elevation of the ground-water mound has decreased as much as $0.28 \mathrm{~m}(0.9 \mathrm{ft})$ (as reflected in the water level in well 299-W19-1). This decline in the elevation of the ground-water mound beneath the deactivated $U$ Pond has been observed in wells in much of the adjacent 200-West Area. This decline is primarily attributed to continued dissipation of the ground-water mound beneath $U$ Pond since it was decommissioned in 1984. A water-table map of the U Pond area for June 1989 is presented in Newcomer et al. (1990). A water-table map of the Separations Area, which includes the deactivated U Pond area, is presented in Kasza et a1. (1989).

\section{$\underline{100-N \text { Area }}$}

The Hanford Site water-table map indicates that ground water passing beneath the 100-N Area flows from the south through the gap between Gable Butte and Gable Mountain and discharges to the Columbia River. The watertable map of the 100-N Area is shown in Figure 3. Water-table maps of the 100-N Area, presented in Smith et al. (1989a, 1989b) and Newcomer et al. (1990), between January and June 1989 indicated a ground-water mound beneath the 1325-N liquid waste disposal facility. Wastewater discharge to this facility was the primary influence on the water table beneath the $100-\mathrm{N}$ Area. The watertable map of the 100-N Area for December 1989, however, indicates that the ground-water mound beneath the $1325-\mathrm{N}$ facility has dissipated significantly since June 1989. The water table is also influenced by wastewater discharged to the $1324 \mathrm{~N} / \mathrm{NA}$ facility and by changes in the stage of the Columbia River. The configuration of the water table is dependent on all the aforementioned influences. 


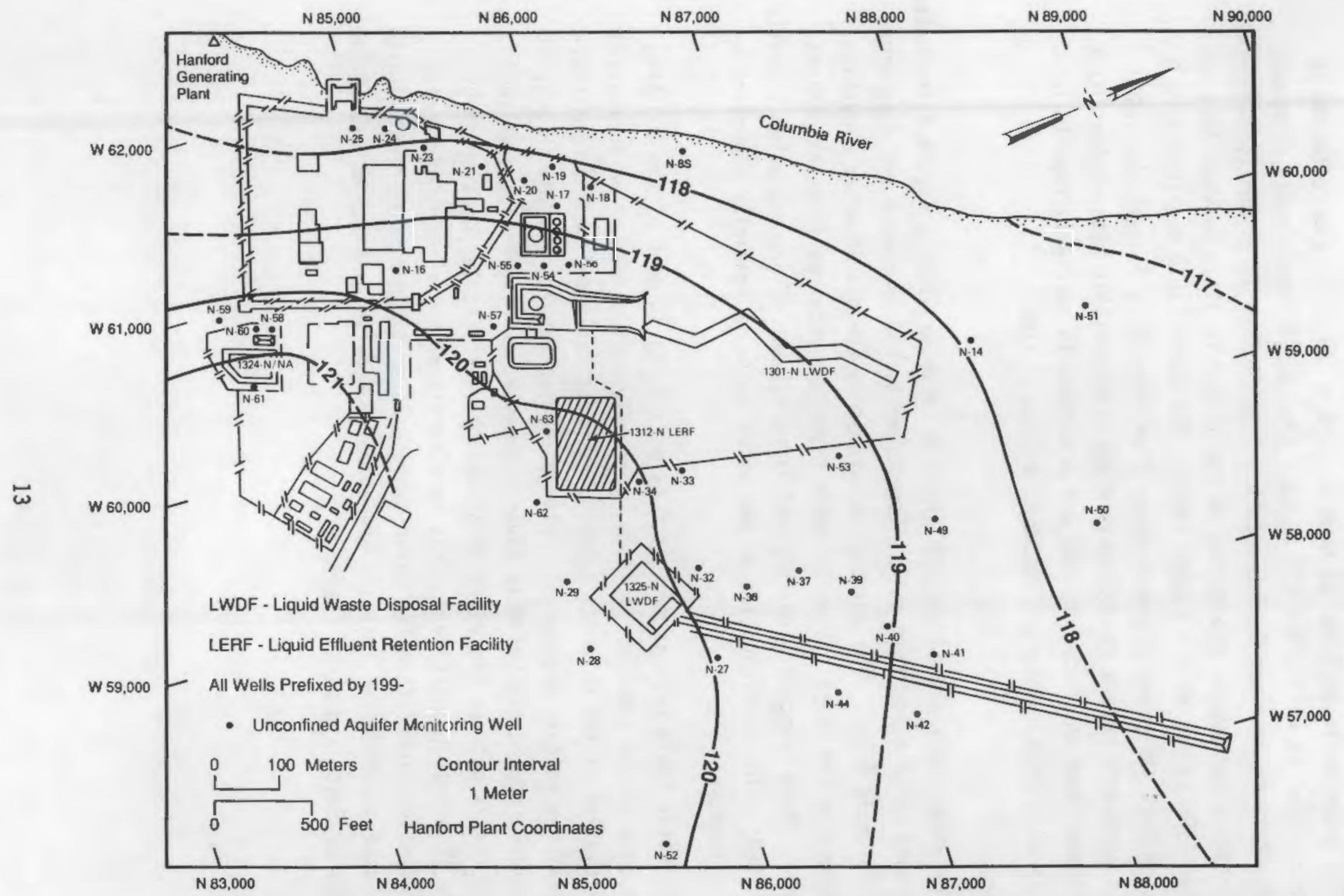

FIGURE 3. Water-Table Map of the Area Beneath the 1325-N Liquid Waste Disposal Facility in the 100-N Area for December 1989 (modified from Smith et al. 1990) 
The water table declined as much as $5.96 \mathrm{~m}$ (19.6 ft) (as reflected in the water level in well 199-N-27) beneath the 1325-N liquid waste disposal facility between June and December 1989. This decline is primarily the result of decreasing wastewater discharged to the $1325-\mathrm{N}$ facility between June and December 1989 (Smith et a1. 1989c; 1990). The water-table map in Figure 3 indicates that the primary ground-water flow directions beneath the $100-\mathrm{N}$ Area is northwest toward the Columbia River. Water-table maps of the 100-N Area between June and December 1989 are presented in quarterly reports by Smith et a1. (1989c; 1990) and by Smith and Gorst (1990).

\section{Area}

The water-table map of the 300 Area for December 1989 in Figure 4 indicates that ground water flows from the northwest, west, and southwest and discharges to the Columbia River. The primary influences on the ground-water elevation are changes in the stage of the Columbia River and recharge from the process trenches. These trenches have received large volumes of process water (Schalla et al. 1988). The configuration of the water table is primarily dependent on these influences.

The water table rose as much as $0.42 \mathrm{~m}(1.4 \mathrm{ft})$ in most of the 300 Area between June 23 and December 27, 1989, primarily as a result of an increasing stage elevation of the Columbia River. The water-table map in Figure 4 indicates that the primary ground-water flow direction beneath the 300 Area is southeasterly toward the Columbia River. However, a "reversed" hydraulic gradient occurs between the river stage and the water table, causing river water to flow into the aquifer. This is a result of the river stage rising to an elevation higher than the water table. Water-table maps of the 300 Area between June and December 1989 are presented in reports by Smith et al. (1989c; 1990) and by Smith and Gorst (1990). 


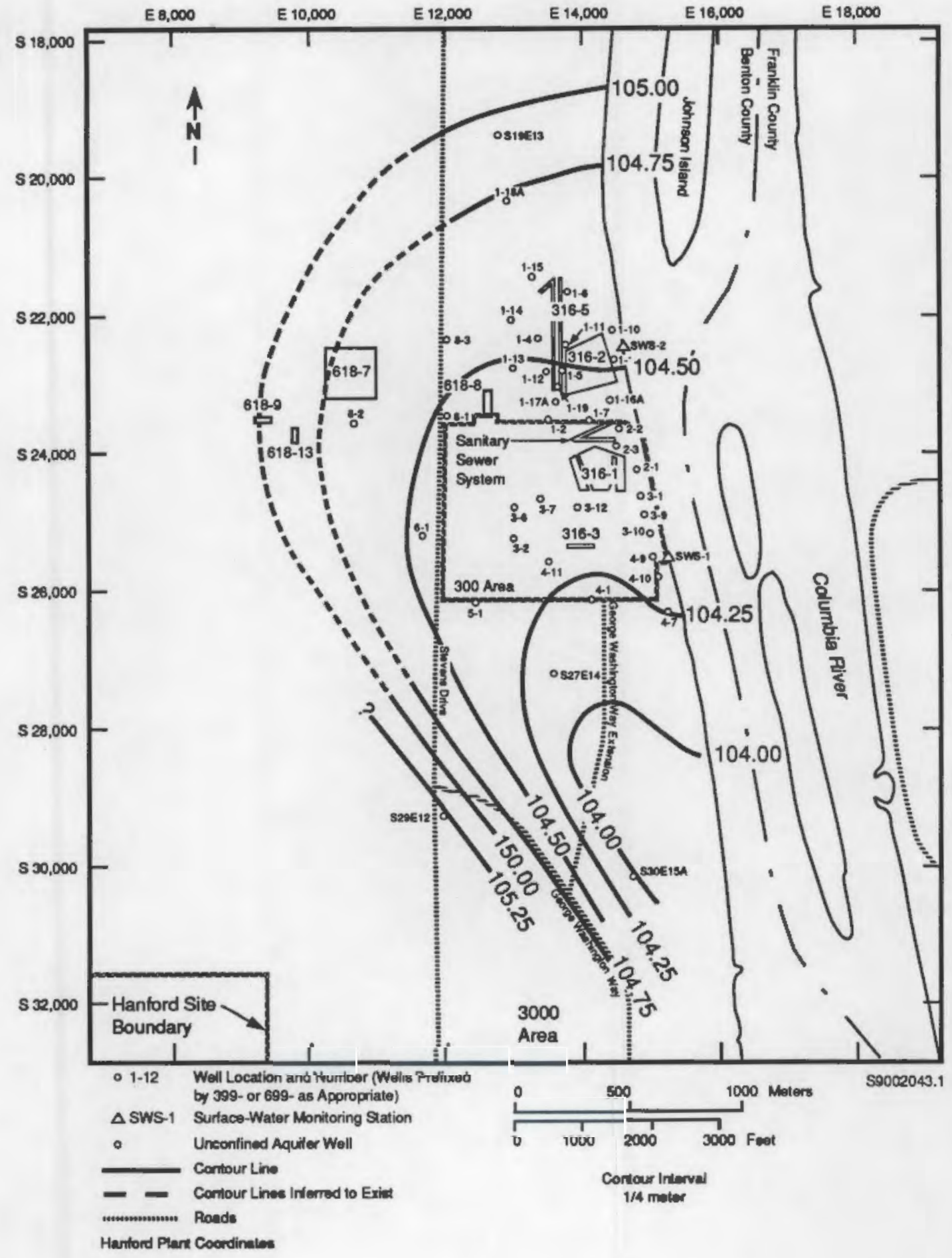

FIGURE 4. Water-Table Map of the Area Beneath the 300 Area for December 1989 (modified from Smith et al. 1990) 



\section{CONCLUSIONS}

Changes to the configuration of the Hanford Site water table are summarized as follows:

- The elevation of the ground-water mound beneath the decommissioned $U$ Pond declined as much as $0.28 \mathrm{~m}(0.9 \mathrm{ft})$ since June 1989, primarily as a result of continued dissipation of the ground-water mound beneath much of the 200 -West Area.

- The elevation of the ground-water mound beneath B Pond declined as much as $0.28 \mathrm{~m}(0.9 \mathrm{ft})$ since June 1989 as a result of decreasing volumes of wastewater discharged to 8 Pond.

- The elevation of the water table beneath the 1325-N liquid waste disposal facility in the 100-N Area decreased approximately $5.96 \mathrm{~m}$ $(19.6 \mathrm{ft})$ between June and December 1989, primarity the result of decreasing wastewater discharged to this facility between June and December 1989.

- Other Hanford discharge facilities known to impact the ground-water flow system include the process trenches in the 300 Area and various cribs and trenches in the 200 Areas. 


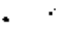




\section{REFERENCES}

ASTM. 1988. "Standard Method for Determining Subsurface Liquid Levels in a Borehole or Monitoring Wel1 (Observation We11)." D 4750-87, American Society for Testing and Materials, Philadelphia, Pennsylvania.

Cooney, F. M., and S. P. Thomas. 1989. Westinghouse Hanford Company Effluent Discharges and Solid Waste Management Report for Calendar Year 1988: 200/600 Areas. WHC-EP-0141-1, Westinghouse Hanford Company, Rich7and, Washington.

EPA. 1986. Resource Conservation and Recovery Act (RCRA) Ground-Water Monitoring Technical Enforcement Guidance Document. OWSER-9950.1, U.S. Environmental Protection Agency, Washington, D.C.

Garber, M. S., and F. C. Koopman. 1968. Methods of Measuring Water Levels in Deep Wells: U.S. Geological Survey TWRI, 8ook 8, Chap. A-1. U.S, Government Printing office, Washington, D.C.

Gephart, R. E., R. C. Arnett, R. G. Baca, L. S. Leonhart, and F. A. Spane, Jr. 1979. Hydrologic Studies Within the Columbia Plateau, Washington: An Integration of Current Knowledge. RHO-BWI-ST-5, Rockwell Hanford Operations, Richland, Washington.

Graham, M. J., M. D. Ha11, S. R. Strait, and W. R. Brown. 1981. Hydrology of the Separations Area. RHO-ST-42, Rockwell Hanford Operations, Richland, Washington.

Kasza, G. L., S. P. ReideT, and A. L. Schatz. 1989. Groundwater Maps of the Hanford Site Separations Area, June 1989. WHC-EP-0142-3, Westinghouse Hanford Company, Richland, Washington.

Newcomer, D. R., J. P. McDonald, and S. M. Goodwin. 1990. Water-Table Elevations on the Hanford Site, June 1989. PNL-7282, Pacific Northwest Laboratory, Richland, Washington.

PNL. 1989. Procedures for Ground-Water Investigations. PNL-6894, Pacific Northwest Laboratory, Richland, Washington.

Schalla, R., R. W. Wallace, R. L. Aaberg, S. P. Airhart, D. J. Bates, J. V. M. Carlile, C. S. Cline, D. 1. Dennison, M. D. Freshley, P. R. Heller, E. J. Jensen, K. B. 01 sen, R. G. Parkhurst, J. T. Rieger, and E. J. Westergard. 1988. Interim Characterization Report for the 300 Area Process Trenches.

PNL-6716, Pacific Northwest Laboratory, Richland, Washington.

Smith, R. M., D. J. Bates, and R. E. Lundgren, editors, 1989a. Resource Conservation and Recovery Act Ground-Water Monitoring Projects for Hanford Facilities: Progress Report for the Period January 1 to March 31, 1989. PNL-6957, Pacific Northwest Laboratory, Richland, Washington. 
Smith, R. M., D. J. Bates, and R. E. Lundgren, editors. 1989b. RCRA GroundWater Monitoring Projects for Hanford Facilities: Progress Report for the Period April l to June 30, 1989. PNL-7134, Pacific Northwest Laboratory, Richland, Washington.

Smith, R. M., D. J. Bates, and R. E. Lundgren, editors. 1989c. RCRA GroundWater Monitoring Projects for Hanford Facilities: Progress Report for the Period July l to September 31, 1989. PNL-7222, Pacific Northwest Laboratory, Richland, Washington.

Smith, R. M., D. J. Bates, and R. E. Lundgren, editors. 1990. RCRA GroundWater Monitoring Projects for Hanford Facilities: Progress Report for the Period October 1 to December 31, 1989. PNL-7305, Pacific Northwest Laboratory, Richland, Washington.

Smith, R. M. and W. R. Gorst, editors, 1990. RCRA Ground-Water Monitoring Projects for Hanford Facilities: Annual Progress Report for 1989. PNL-7305, Pacific Northwest Laboratory, Richland, Washington.

USGS. 1977. National Handbook of Recommended Methods for Water Data Acquisition. U.S. Geological Survey, Office of Water Data Coordination, Reston, Virginia.

Zimunerman, D. A., A. E. Reisenauer, G. D. Black, and M. A. Young. 1986. Hanford Site Water Table Changes 1950 Through 1980-Data Observations and Evaluation. PNL-5506, prepared for Rockwe11 Hanford Operations by Pacific Northwest Laboratory, Richland, Washington. 
APPENDIX A

WATER-LEVEL MEASUREMENTS FOR THE HANFORD SITE 
APPENDIX A

WATER-LEVEL MEASUREMENTS FOR THE HANFORD SITE

TABLE_A.1. Hanford Site Water-Level Measurements in Unconfined Aquifer Wells, December 1989

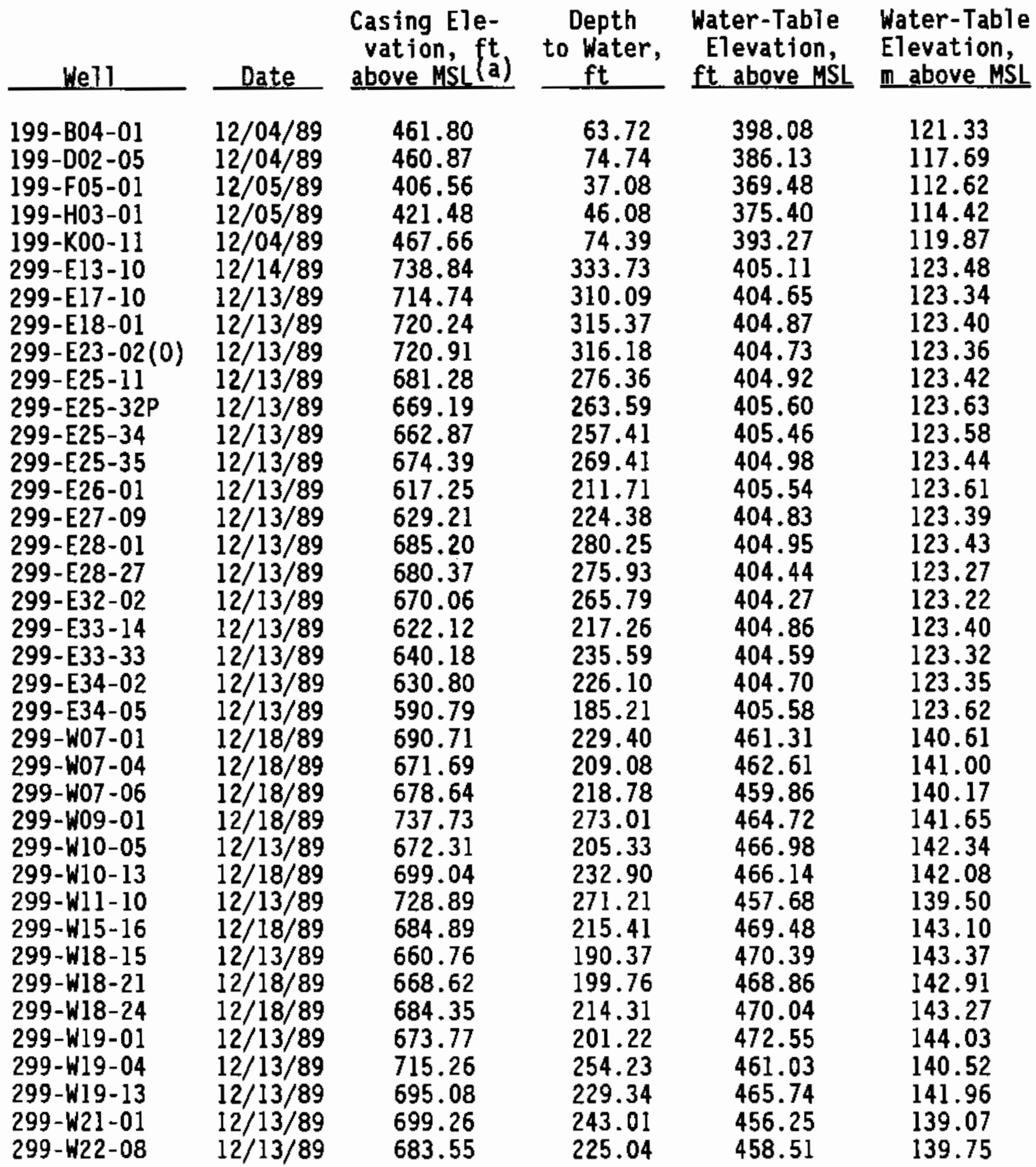


TABLE A.1. (contd)

\begin{tabular}{c}
$\begin{array}{c}\text { Casing Ele- } \\
\text { vation, ft } \\
\text { above MSL (a) }\end{array}$ to Water, $\begin{array}{c}\text { Water-Table } \\
\text { Elevation, } \\
\text { ft. }\end{array}$ \\
\hline
\end{tabular}

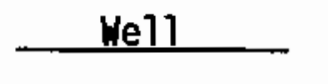

Date

299-W23-11

$12 / 13 / 89$

399-08-01

$12 / 11 / 89$

699-02-03

699-02-33A

$12 / 12 / 89$

$12 / 11 / 89$

699-03-45

699-08-17

$12 / 11 / 89$

$12 / 12 / 89$

699-08-25

699-08-32

699-09-E02

$12 / 11 / 89$

$12 / 11 / 89$

$12 / 12 / 89$

699-10-54B

$12 / 07 / 89$

699-10-E12

699-11-45A

699-14-38

699-14-47

$699-15-15 A$

699-15-26

699-17-05

699-17-70

699-19-43

699-19-58

699-19-88

699-20-20

699-20-39

699-20-E12

699-21-17

699-24-01T

699-24-33

699-25-55

699-25-70

699-26-15A

699-26-89

699-27-08

699-28-40

699-28-52A

699-29-78

699-31-31

699-32-22

699-32-43

699-32-62

699-32-708

699-32-72

$699-32-77$

699-33-56

699-34-39A

$12 / 08 / 89$

$12 / 07 / 89$

$12 / 07 / 89$

$12 / 07 / 89$

$12 / 11 / 89$

$12 / 11 / 89$

$12 / 12 / 89$

$12 / 22 / 89$

$12 / 07 / 89$

$12 / 07 / 89$

$12 / 11 / 89$

$12 / 12 / 89$

$12 / 07 / 89$

$12 / 08 / 89$

$12 / 08 / 89$

$12 / 08 / 89$

$12 / 07 / 89$

$12 / 14 / 89$

$12 / 07 / 89$

$12 / 08 / 89$

$12 / 11 / 89$

$12 / 08 / 89$

$12 / 07 / 89$

$12 / 14 / 89$

$12 / 06 / 89$

$12 / 07 / 89$

$12 / 07 / 89$

$12 / 07 / 89$

$12 / 07 / 89$

$12 / 07 / 89$

$12 / 07 / 89$

$12 / 07 / 89$

$12 / 14 / 89$

$12 / 07 / 89$

699-34-41B

$12 / 07 / 89$

664.14

$394.8 B$

477.14

536.37

504.54

522.44

509.30

554.39

418.09

516.20

430.86

578.58

514.89

587.23

547.14

523.83

433.19

563.18

551.58

573.05

644.45

505.58

539.98

437.25

527.31

475.54

524.21

676.55

629.78

442.64

653.08

465.67

559.44

684.67

647.05

529.32

517.55

516.62

707.09

666.68

668.16

653.74

717.03

537.07

570.89
$197.01 \quad 467.13$

$51.99 \quad 342.89$

$86.64 \quad 390.50$

$132.70 \quad 403.67$

$93.09 \quad 411.45$

$123.38 \quad 399.06$

108.78

153.48

46.13

103.19

73.62

167.01

110.39

175.38

147.93

121.70

44.69

88.83

146.43

153.83

131.44

103.35

135.52

79.70

129.00

98.87

120.25

262.85

180.73

43.28

180.12

70.64

154.88

278.53

182.93

125.34

115.63

111.87

277.94

214.45

213.58

190.84

311.21

132.43

166.07
400.52

400.91

371.96

413.01

357.24

411.57

404.50

411.85

399.21

402.13

388.50

474.35

405.15

419.22

513.01

402.23

404.46

357.55

398.31

376.67

403.96

413.70

449.05

399.36

472.96

395.03

404.56

406.14

464.12

403.98

401.92

404.75

429.15

452.23

454.58

462.90

405.82

404.64

404.82
142.38

104.51

119.02

123.04

125.41

121.63

122.08

122.20

113.37

125.89

108.89

125.45

123.29

125.53

121.68

122.57

118.41

144.58

123.49

127.78

156.37

122.60

123.28

108.98

121.40

114.81

123.13

126.10

136.87

121.72

144.16

120.41

123.31

123.79

141.46

123.13

122.51

123.37

130.80

137.84

138.56

141.09

123.69

123.33

123.39 
TABLE A.1. (contd)

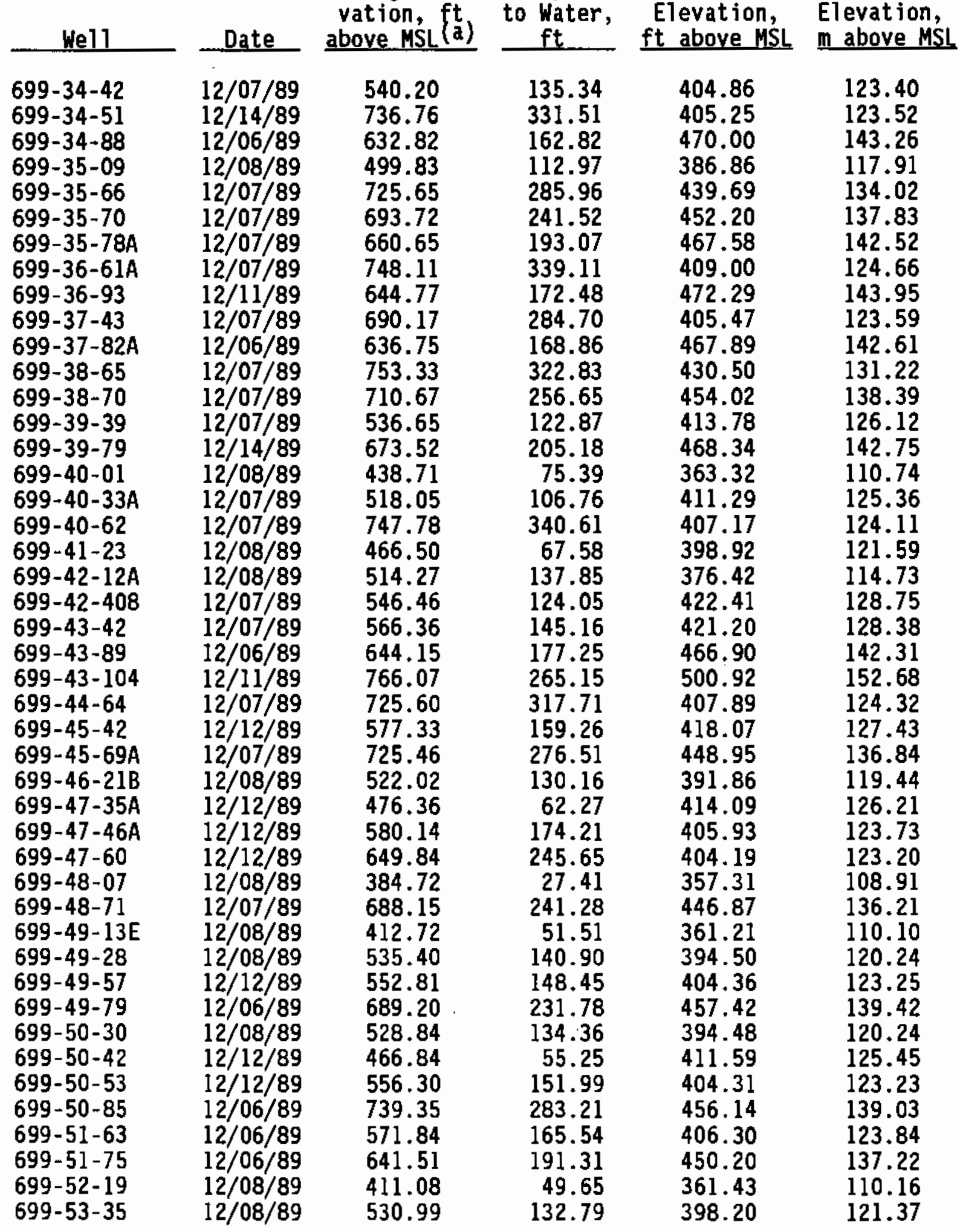


TABLE A.1. (contd)

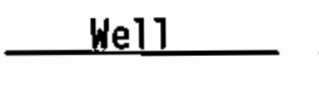

$699-53-48 B$
$699-53-55 C$
$699-54-19$
$699-54-34$
$699-54-37 A$
$699-54-42$
$699-54-45 A$
$699-54-48$

$-54-48$

699-55-40

699-55-44

699-55-50C

699-55-70

699-55-76

699-55-89

699-55-95

699-56-43

699-57-25A

699-57-29B

699-57-83A

699-58-24

699-59-32

699-59-58

699-59-80B

699-60-32

$699-60-60$

699-61-37

699-61-41

699-61-62

699-61-66

699-62-31

$699-62-43 A$

699-63-25A

699-63-51

699-63-58

699-63-90

699-64-27

699-64-62

699-65-50

699-65-59A

699-65-72

699-65-83

699-65-95

699-66-23

$699-66-38$
Date

$12 / 08 / 89$

$12 / 08 / 89$

$12 / 05 / 89$

$12 / 08 / 89$

$12 / 08 / 89$

$12 / 08 / 89$

$12 / 08 / 89$

$12 / 08 / 89$

$12 / 05 / 89$

$12 / 08 / 89$

$12 / 08 / 89$

$12 / 08 / 89$

$12 / 06 / 89$

$12 / 06 / 89$

$12 / 04 / 89$

$12 / 06 / 89$

$12 / 08 / 89$

$12 / 05 / 89$

$12 / 05 / 89$

$12 / 06 / 89$

$12 / 05 / 89$

$12 / 05 / 89$

$12 / 06 / 89$

$12 / 06 / 89$

$12 / 05 / 89$

$12 / 06 / 89$

$12 / 05 / 89$

$12 / 05 / 89$

$12 / 06 / 89$

$12 / 06 / 89$

$12 / 05 / 89$

$12 / 05 / 89$

$12 / 05 / 89$

$12 / 05 / 89$

$12 / 06 / 89$

$12 / 04 / 89$

$12 / 05 / 89$

$12 / 06 / 89$

$12 / 05 / 89$

$12 / 06 / 89$

$12 / 06 / 89$

$12 / 04 / 89$

$12 / 04 / 89$

$12 / 05 / 89$

$12 / 05 / 89$
Casing Elevation, ft above MSL (a)

442.71

576.08

383.60

550.24

534.17

511.49

494.29

457.02

395.96

543.13

519.67

444.43

569.03

583.24

617.43

777.05

540.42

414.57

416.18

577.96

418.80

424.29

497.77

583.25

425.30

512.03

442.94

428.92

497.51

522.18

434.12

432.30

395.15

424.54

491.90

509.73

414.29

500.25

467.06

506.96

540.28

485.63

452.26

389.01

436.20
Depth to Water, $\mathrm{ft}$

38

38.1

172.48

22.09

140.87

124.91

115.45

96.43

53.50

35.68

133.04

124.35

40.92

136.49

138.66

162.30

311.10

130.94

50.71

54.55

145.10

57.29

62.38

95.10

154.77

63.58

108.70

60.79

32.55

94.25

119.95

72.45

35.57

33.73

24.00

90.01

112.61

52.68

98.74

66.50

105.52

141.16

87.64

54.44

28.40

33.24
Water-Table Water-Table

Elevation, Elevation, $\mathrm{ft}$ above MSL 1 above MSL

$\begin{array}{ll}404.59 & 123.32 \\ 403.60 & 123.02 \\ 361.51 & 110.19 \\ 409.37 & 124.78 \\ 409.26 & 124.74 \\ 396.04 & 120.71 \\ 397.86 & 121.27 \\ 403.52 & 122.99 \\ 360.28 & 109.81 \\ 410.09 & 125.00 \\ 395.32 & 120.49 \\ 403.51 & 122.99 \\ 432.54 & 131.84 \\ 444.58 & 135.51 \\ 455.13 & 138.72 \\ 465.95 & 142.02 \\ 409.48 & 124.81 \\ 363.86 & 110.90 \\ 361.63 & 110.22 \\ 432.86 & 131.94 \\ 361.51 & 110.19 \\ 361.91 & 110.31 \\ 402.67 & 122.73 \\ 428.48 & 130.60 \\ 361.72 & 110.25\end{array}$

361.72

403.33

382.15

396.37

403.26

402.23

361.67

396.73

361.42

400.54

401.89

397.12

361.61

401.51

400.56

401.44

399.12

397.99

397.82

360.61

402.96
110.25

122.94

116.48

122.91

122.60

110.24

120.92

110.16

122.08

122.50

121.04

110.22

122.38

122.09

122.36

121.65

121.31

121.26

109.91

122.82
120.81 


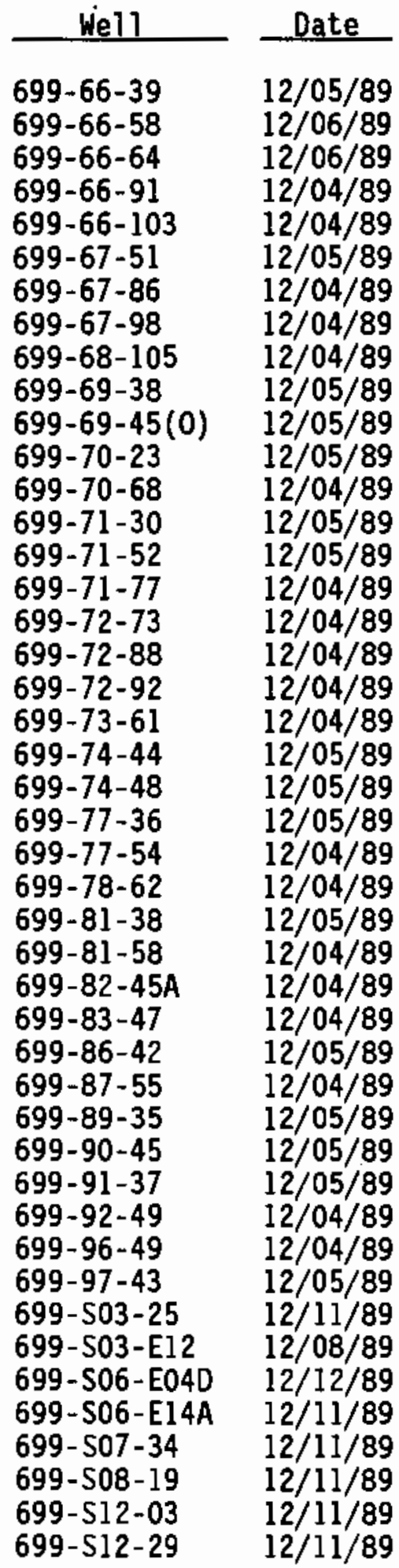

\begin{tabular}{|c|c|c|c|}
\hline $\begin{array}{l}\text { Casing Ele- } \\
\text { vation, ft } \\
\text { above MSL (a) }\end{array}$ & $\begin{array}{c}\text { Depth } \\
\text { to Water, } \\
\mathrm{ft} \\
\end{array}$ & $\begin{array}{l}\text { Water-Table } \\
\text { Elevation, } \\
\text { ft above MSL } \\
\end{array}$ & $\begin{array}{l}\text { Water-Tabl } \\
\text { Elevation, } \\
\text { II above MS }\end{array}$ \\
\hline $\begin{array}{l}453.70 \\
503.33 \\
505.92 \\
467.75 \\
463.01 \\
524.59 \\
472.39 \\
455.47 \\
451.85 \\
422.93 \\
486.94 \\
391.71 \\
526.21 \\
400.68 \\
523.04 \\
472.28 \\
482.57 \\
437.37 \\
452.22 \\
531.53 \\
445.18 \\
487.18 \\
412.28 \\
480.59 \\
469.88 \\
406.47 \\
439.55 \\
413.73 \\
435.27 \\
409.92 \\
458.63 \\
397.46 \\
422.15 \\
422.93 \\
432.00 \\
419.29 \\
421.81 \\
523.50 \\
397.90 \\
430.47 \\
378.29 \\
527.12 \\
503.81 \\
435.52 \\
487.68\end{array}$ & $\begin{array}{r}47.15 \\
102.03 \\
105.19 \\
69.19 \\
66.20 \\
123.93 \\
74.68 \\
57.75 \\
57.05 \\
21.29 \\
87.30 \\
29.88 \\
126.72 \\
30.17 \\
123.00 \\
75.90 \\
85.40 \\
37.82 \\
54.03 \\
131.63 \\
48.22 \\
88.29 \\
36.09 \\
82.33 \\
73.79 \\
27.23 \\
41.71 \\
24.57 \\
46.05 \\
25.22 \\
69.99 \\
27.18 \\
37.51 \\
50.28 \\
48.68 \\
37.81 \\
43.32 \\
123.78 \\
43.75 \\
58.14 \\
28.30 \\
119.34 \\
107.10 \\
55.05 \\
83.42\end{array}$ & $\begin{array}{l}406.55 \\
401.30 \\
400.73 \\
398.56 \\
396.81 \\
400.66 \\
397.71 \\
397.72 \\
394.80 \\
401.64 \\
399.64 \\
361.83 \\
399.49 \\
370.51 \\
400.04 \\
396.38 \\
397.17 \\
399.55 \\
398.19 \\
399.90 \\
396.96 \\
398.89 \\
376.19 \\
398.26 \\
396.09 \\
379.24 \\
397.84 \\
389.16 \\
389.22 \\
384.70 \\
388.64 \\
370.28 \\
384.64 \\
372.65 \\
383.32 \\
381.48 \\
378.49 \\
399.72 \\
354.15 \\
372.33 \\
349.99 \\
407.78 \\
396.71 \\
380.47 \\
404.26\end{array}$ & $\begin{array}{l}123.92 \\
122.32 \\
122.14 \\
121.48 \\
120.95 \\
122.12 \\
121.22 \\
121.23 \\
120.34 \\
122.42 \\
121.81 \\
110.29 \\
121.76 \\
112.93 \\
121.93 \\
120.82 \\
121.06 \\
121.78 \\
121.37 \\
121.89 \\
120.99 \\
121.58 \\
114.66 \\
121.39 \\
120.73 \\
115.59 \\
121.26 \\
118.62 \\
118.63 \\
117.26 \\
118.46 \\
112.86 \\
117.24 \\
113.58 \\
116.84 \\
116.28 \\
115.36 \\
121.83 \\
107.94 \\
113.49 \\
106.68 \\
124.29 \\
120.92 \\
115.97 \\
123.22\end{array}$ \\
\hline
\end{tabular}


IABLE A.1. (contd)

\begin{tabular}{|c|c|c|c|c|c|}
\hline Well & Date & $\begin{array}{c}\text { Casing Ele- } \\
\text { vation, ft } \\
\text { above MSL (a) }\end{array}$ & $\begin{array}{c}\text { Depth } \\
\text { to Water, } \\
\mathrm{ft} \\
\end{array}$ & $\begin{array}{c}\text { Water-Table } \\
\text { Elevation, } \\
\mathrm{ft} \text { above MSL }\end{array}$ & $\begin{array}{l}\text { Water-Table } \\
\text { Elevation, } \\
\text { m above MSL }\end{array}$ \\
\hline $\begin{array}{l}699-S 14-20 A \\
699-S 18-E 02 A \\
699-S 19-11 \\
699-S 19-E 13 \\
699-S 29-E 12 \\
699-S 30-E 15 A \\
699-S 3 I-01\end{array}$ & $\begin{array}{l}12 / 11 / 89 \\
12 / 11 / 89 \\
12 / 11 / 89 \\
12 / 11 / 89 \\
12 / 11 / 89 \\
12 / 11 / 89 \\
12 / 11 / 89\end{array}$ & $\begin{array}{l}492.74 \\
434.85 \\
483.74 \\
394.51 \\
387.95 \\
400.14 \\
460.11\end{array}$ & $\begin{array}{l}92.05 \\
75.60 \\
94.47 \\
50.48 \\
42.41 \\
57.84 \\
84.36\end{array}$ & $\begin{array}{l}400.69 \\
359.25 \\
389.27 \\
344.03 \\
345.54 \\
342.30 \\
375.75\end{array}$ & $\begin{array}{l}122.13 \\
109.50 \\
118.65 \\
104.86 \\
105.32 \\
104.33 \\
114.53\end{array}$ \\
\hline
\end{tabular}

(a) $M S L=$ mean sea level. 


\section{APPENDIX B}

WATER-LEVEL MEASUREMENTS AT SPECIFIC HANFORD SITE AREAS 
APPENDIX B

\section{WATER-LEVEL MEASUREMENTS AT SPECIFIC HANFORD SITE AREAS}

IABLE B.1. Decommissioned 216-U-10 Pond Water-Level Measurements in Unconfined Aquifer We11s, December 1989

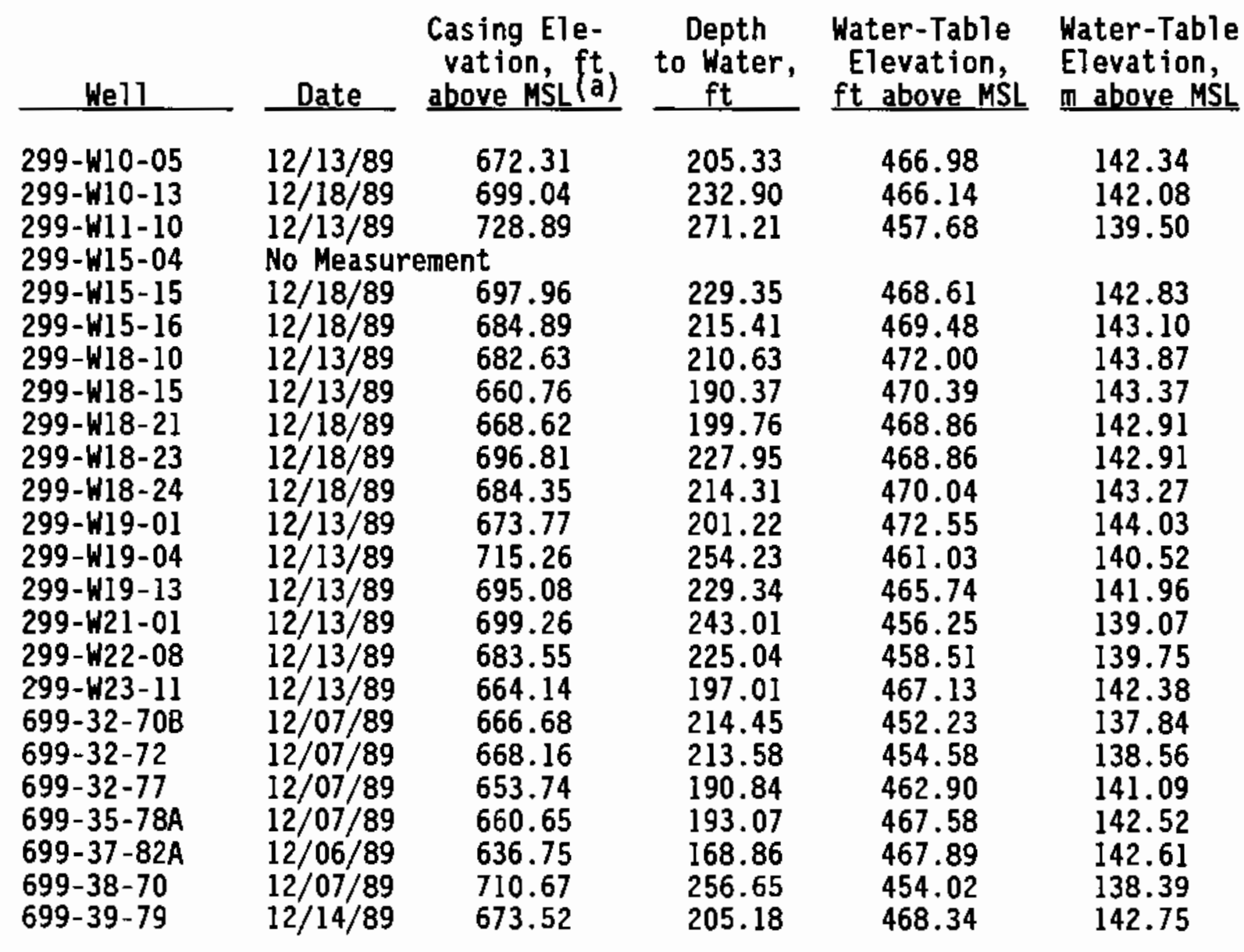

(a) MSL = mean sea level. 
IABLE B.2. 216-B-3 Pond Water-Level Measurements in Unconfined Aquifer We11s, December 21, 1989

Well above MSL $(a)$

299-E25-32P

699-39-39

$699-40-33 A$

$699-40-39$

$699-41-40$

$699-42-40 B$

$699-43-41 E$

$699-43-42 J$

$699-43-43$

$699-43-45$

699-44-42

699-44-43B

699-45-42

699-47-35A

699-47-46A
669.19

536.65

518.05

541.84

545.94

546.46

550.86

581.68

579.37

597.68

579.22

580.12

577.33

476.36

580.14
Depth
to Water,

$\mathrm{ft}$

263.65

121.44

106.87

127.89

129.39

124.42

129.56

162.35

164.24

191.50

158.22

164.54

159.40

62.33

174.29
Water-Table Water-Table

Elevation, Elevation, ft above MSL m above MSL

405.54

415.21

411.18

413.95

416.55

422.04

421.30

419.33

415.13

406.18

421.00

415.58

417.93

414.03

405.85
123.61
126.56
125.33
126.17
126.96
128.64
128.41
127.81
126.53
123.80
128.32
126.67
127.39
126.20
123.70

(a) $M S L=$ mean sea level. 
TABLE B.3. 100-N Area Water-Leve1 Measurements in Unconfined Aquifer We11s, December 28, 1989

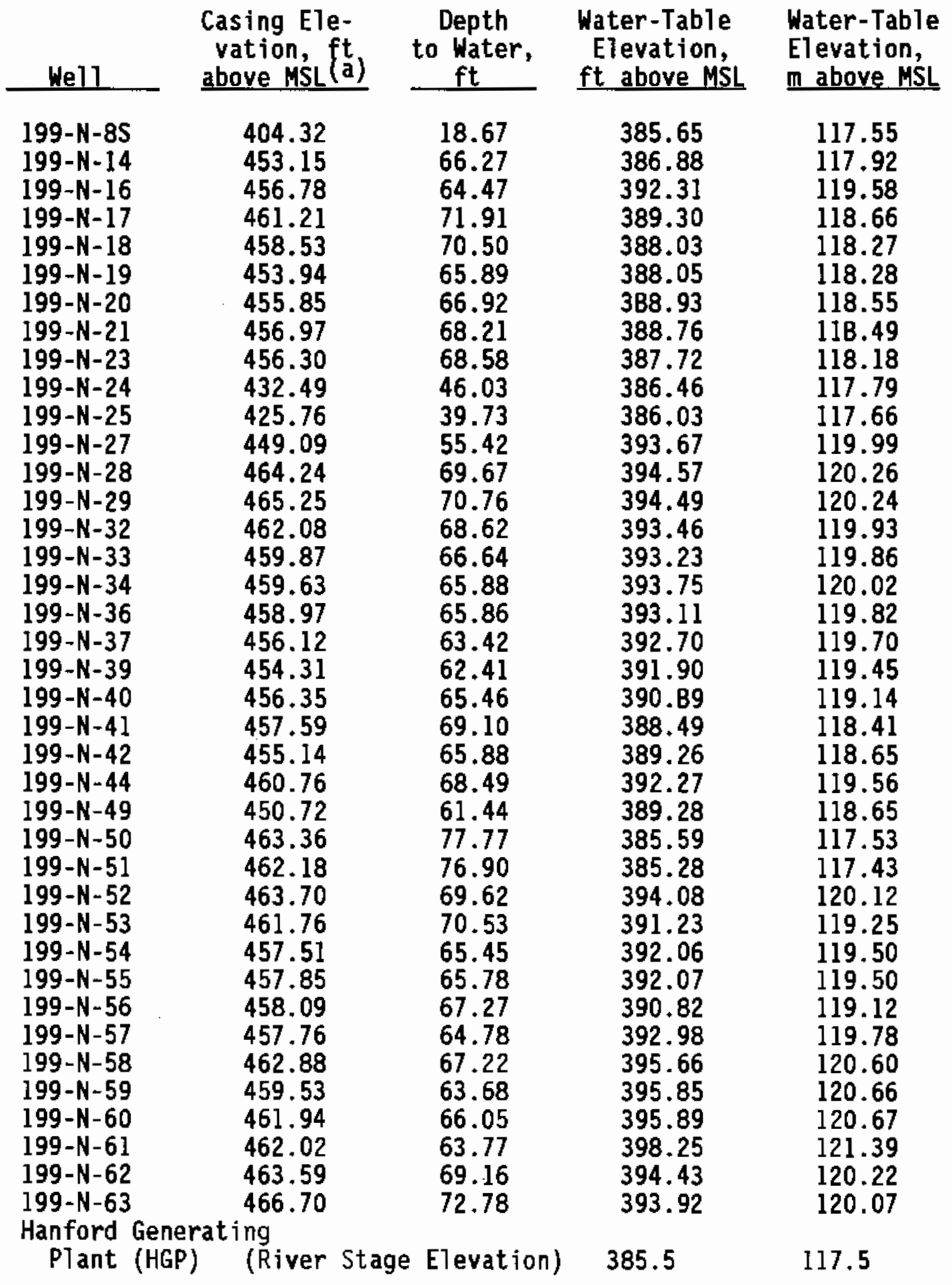

(a) MSL = mean sea level. 
TABLE B.4. 300 Area Water-Level Measurements in Unconfined Aquifer Hells, December 27, 1989

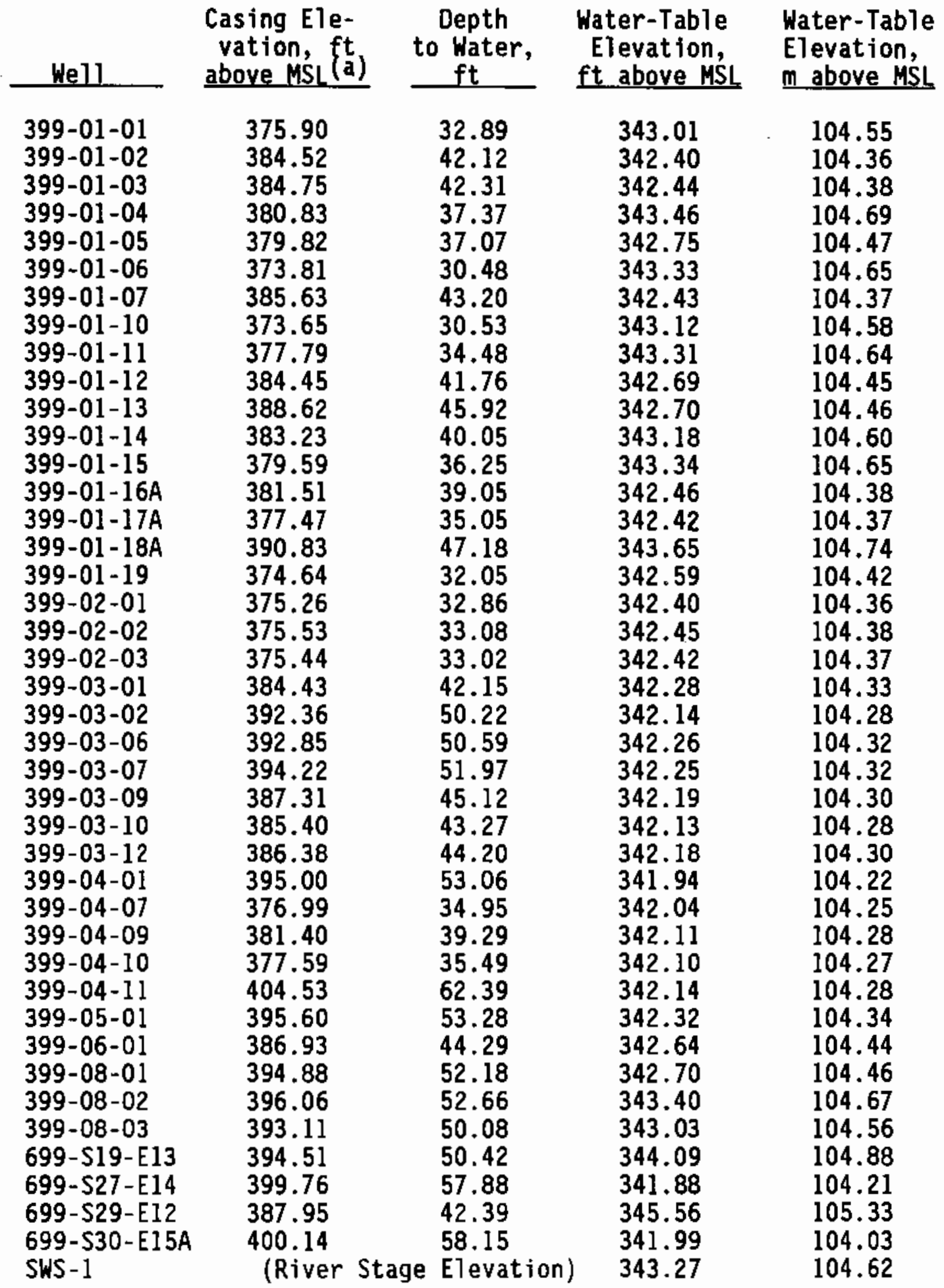

(a) $\mathrm{MSL}=$ mean sea level. 
PNL -7374

UC -903

\section{DISTRIBUTION}

No. of

Copies

OFFSITE

2 DOE/Office of Scientific and Technical Information

\section{ONSITE}

22 DOE-Richland Operations office

G. M. Be]l

R. G. Holt

M. W. Tiernan (20)

17 Westinghouse Hanford Company

M. R. Adams

L. C. Brown

G. D. Carpenter

M. A. Christie

L. P. Diediker

J. J. Dorian

K. R. Fecht

K. A. Gano

E. M. Greager

R. L. Jackson

G. L. Kasza

A. G. Law

D. L. Lund

R. G. McCain

J. A. Serkowski

L. C. Swanson

Public Reading Room
No. of

Copies

49 Pacific Northwest Laboratory

D. J. Bates

J. V. Borghese

R. W. Bryce

M. A. Chamness

J. C. Evans

J. W. Falco

M. D. Freshley (Mark)

R. M. Fruland

R. E. Gephart

T. J. Gilmore

W. R. Gorst

R. H. Gray (2)

J. M. Hales

S. H. Hall

M. S. Hanson

P. C. Hays

P. E. Long

S. P. Luttre11

J. P. McDonald

R. W. Nelson

D. R. Newcomer (15)

J. T. Rieger

L. E. Rogers

R. Schalla

W. T. Pennel1

R. L. Skaggs

R. M. Smith

S. S. Tee]

E. J. Westergard

R. W. Wallace

Publishing Coordination

Technica? Report Files (5) 


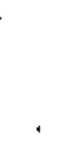




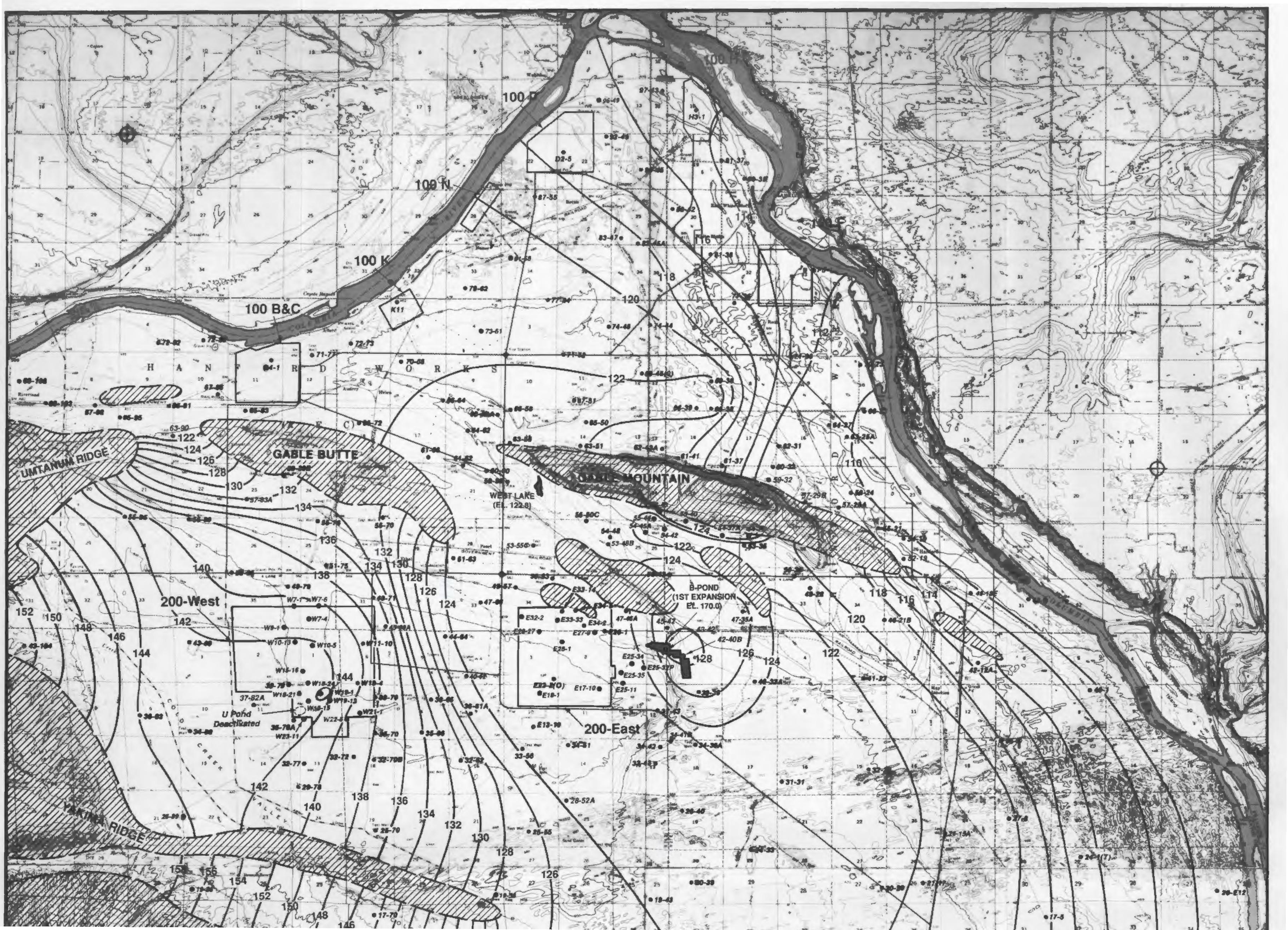


